\title{
The Growing Family of Limb-Girdle Muscular Dystrophies: Old and Newly Identified Members
}

\author{
ALEXANDRA BASTIAN ${ }^{1,2}$, V. MAGERIU ${ }^{1}$, GIANINA MICU ${ }^{1}$, EMILIA MANOLE $^{3}$ \\ 1“"Colentina" University Hospital, Department of Pathology, Bucharest, Romania \\ ${ }^{2}$ University of Medicine and Pharmacy, Department of Pathology, Bucharest, Romania \\ 3 "Victor Babeş" National Institute of Pathology, Molecular Biology Laboratory, Bucharest, Romania
}

\begin{abstract}
Limb-girdle muscular dystrophies (LGMD) are an extremely heterogeneous and rapidly expanding group of diseases characterized by progressive weakness of pelvic, scapular and trunk muscles with sparing of facial and distal musculature in most of the subtypes, onset in childhood or in adults of both sexes, very variable clinical severity ranging from mild to severe phenotypes, some associated with cardio-pulmonary and extraskeletal impairment and high serum creatine-kinase (CK) levels. In the past years, huge advances have been recorded in the various identification methods and new distinct entities were discovered. However, it is not yet clear why some muscle groups are affected and others spared in a specific subtype of LGMD, why similar clinical pictures are associated with different genes and mutations, while the same gene or mutation may present with very various clinical phenotypes [1]. In this review we summarize the main aspects of positive and differential diagnosis in LGMD.
\end{abstract}

Key words: Limb-girdle muscular dystrophies, calpain 3, dysferlin, anoctamin $5, \gamma, \alpha, \beta$ and $\delta$ sarcoglycans.

\section{OVERVIEW}

LGMD have been first defined in 1954 by Walton and Natrass, but early description of LGMD dates back to the late eighteenth century, with the first observations and description of patients made by Erb and Leyden-Mobius [2]. The LGMD are caused, in our actual knowledge, by autosomal recessive or dominant mutations in many different genes encoding for distinctive types of proteins, with completely different functions, located in all muscle cell compartments: sarcolemma, nuclear membrane, sarcomere, cytosol or the extracellular space. Nowadays, we have 30 distinct LGMD subtypes and other entities are new candidates, so every year an updated classification table is published online. More than $90 \%$ of the cases are autosomal recessive in aetiology and are known as type 2 LGMD, subsequently classified with letters, in an alphabetical order, in chronological accordance to the order of their discovery. Less than $10 \%$ are type 1 LGMD (autosomal dominant) and we recognize now eight different subtypes, LGMD $1 \mathrm{~A}-\mathrm{H}$, of which many were found in only few families. Obviously, soon the letters of the alphabet are going to be insufficient for the expanding recessive group [3-5].

\section{ACTUAL CHALLENGES IN LGMD}

Worldwide, is estimated that around 30\% of the patients with obvious clinical picture of LGMD do not have an identifiable proteomic cause for their illness, complete understanding of the pathophysiology is lacking and the precise function of each of the implicated proteins, as well as the protein interactions in the complexity of muscle function are mostly unknown, prompting future research. Complete immunophenotyping and genotype analysis are not available everywhere, making the achievement of a precise diagnosis difficult, especially in sporadic patients, thus they require a comprehensive multiprofessional clinical evaluation and a complex laboratory approach. A precise positive and differential diagnosis in LGMD is essential, not only for prognostic purposes and early management of respiratory and cardiac complications, but also for genetic counseling, in waiting for future specific genetic therapies. A key aspect is also the psychological impact of a clearly established diagnosis for the patient and his family [6].

\section{EPIDEMIOLOGY}

LGMD are the fourth most common genetic muscle condition (after dystrophinopathies, faciosca- 
pulohumeral muscular dystrophy and myotonic dystrophy) with a minimum prevalence of approximately 1/20000 in some countries, while in England, Mexico and Turkey LGMD are considered the second most common muscular dystrophy after dystrophinopathies, with a disease prevalence of up to $1 / 14500$ and a carrier frequency of up to $1 / 150$ $[1,4,7,8,9]$.

Even among the subtypes, there are great differences between various populations. For instance, LGMD 2A is the most common form in some European countries like Spain, Italy, Czech Republic, Romania (personal observation), while in others, such as England or Denmark, LGMD 2I is the most prevalent type of LGMD. In Turkey and North Africa, as well as in Brasil, sarcoglycanopathies (LGMD 2C-2F) have a high relative proportion $[10,11,4,6,12]$. Some types of LGMD have been identified only in very few populations, for example LGMD 2J, a new form of LGMD was described in Finland and LGMD 2H was observed only in Manitoba Hutterites until now [13-16].

The global prevalence of the different LGMD subtypes is still difficult to accurately establish due to the fact that while some countries published detailed population studies of patients with diverse genetic muscle diseases including LGMD, many others, including Romania, only had sporadic reports of cases and no cohort study. The major advances in immunohistochemistry, immunoblotting and especially in the field of molecular genetics with the new techniques of whole exome sequencing are soon going to improve the current situation and our knowledge.

\section{CLINICAL ASPECTS IN LGMD}

A thorough clinical examination is essential for directing futher investigation and all types of LGMD share the same predilection for proximal shoulder and pelvic girdle musculature, but involvement of distal muscles is also present in some cases. The onset age is very variable, even in patients with the same mutation, from neonatal to middle age (usually in late childhood or early adulthood) as well as the disease course. In most cases, the weakness starts in the pelvic girdle and spreads to the trunk and shoulder muscles. The autosomal dominant subtypes start later and have a slower progression, but there are exceptions. Weakness and atrophy involve certain muscle groups with sparing of others and produce characteristic appearances: scapular winging, anterior axillary fold or dropped shoulders, excessive lombar lordosis and waddling gait [6]. The selective involvement of different muscles in different subtypes has not been understood yet.

Pseudohypertrophy of the calf musculature or other limb muscles may be present in some of the recessive subtypes, like LGMD 2C-F, 2I and may lead to a wrong diagnosis of dystrophinopathy. Muscle tendon reflexes, preserved in early stages, are later lost.

Cardiac involvement in the form of dilated or hypertrophic cardiomyopathy and dysrhythmias are present in LGMD 2C-F, 2I and 1B, subtypes that may also have respiratory muscle weakness with nocturnal hypoventilation.

Contractures are part of the early or late clinical picture in LGMD 1B and in a milder form in LGMD 2A. Rigidity of spine is frequent in LGMD $1 \mathrm{~B}$ and sometimes can be seen in LGMD 2A, while scoliosis is most commonly encountered in sarcoglycanopathies.

Abnormalities of the central nervous system with mental retardation are rarely seen in LGMD 2I and $2 \mathrm{~K}[4,12]$.

\section{AUTOSOMAL DOMINANT LGMD}

LGMD 1A (5q) is caused by mutations in the gene for myotilin, a thin filament associated sarcomeric protein of the Z- band, that help stabilize and anchor thin filaments during sarcomere assembly. Several families were described around the world, suggesting a spectrum of phenotypic aspects, including proximal/distal weakness and dysarthria, tight Achilles tendons and cardiac involvement [17-19].

LGMD 1B (1q) is the result of mutations in LMNA gene, encoding for the lamin $A / C$, intermediate filaments of the nuclear lamina, in charge with the structural integrity of the inner nuclear membrane and nuclear pore complexes. Different mutations in the LMNA gene are associated with very diverse phenotypes. The early clinical features are mild proximal weakness starting in childhood and contractures, followed by cardiac abnormalities with arrhythmias, conduction disturbances and dilated cardiomyopathy leading to sudden death [20-22].

LGMD 1C (3p) is caused by mutation in CAV 3 gene, encoding for caveolin 3, a musclespecific structural protein of the caveolae, invaginations of the plasma membrane essential in cellular trafficking and interacting with dysferlin. Mutations of CAV 3 gene are also associated with the rippling muscle disease, with a form of distal 
myopathy and with idiopathic and familial isolated hyperCKemia. In LGMD 1C mild muscle weakness, cramping, and calf hypertrophy start in the first years of life [23-29].

LGMD 1D (6q), sometimes classified as 1E, is the result of defects in DNAJB6 protein, a member of the heat shock protein 40/DNAJB family of molecular co-chaperone involved in protection from irreversible aggregation in protein synthesis and cellular stress. Onset is in middle adulthood with slowly progressive leg weakness with foot drop and no systemic features [3-5].

LGMD 1E (2q), in some classifications 1D, results from mutations in the desmin gene. Desmin is a vimentin-like major intermediate filament linking myofibrils to the sarcolemma, nucleus and mitochondria, involved also in mechanical and structural integrity and transmission of force. Desmin mutations lead to familial dilated cardiomyopathy with conduction defects and muscular dystrophy, with slowly progressive proximal weakness starting in the second decade or later, congestive heart failure, arrhythmia or sudden death. [4].

LGMD1F (7q), described in one large Spanish family, is due to mutation in TNPO3 gene coding for transportin3, a nuclear protein involved in protein transport into nucleus. Phenotypes of the family members were variable, with adult or juvenile onset of shoulder and pelvic weakness, but no cardiac involvement or contractures [30].

LGMD $1 G$ (4p), described in a Brasilian family, results in dominant mutations in the gene for heterogeneous nuclear ribonucleoprotein D-like protein (HRNPDL) involved in RNA-processing events and linked with transportin 3 . The disease has a homogeneous phenotype with variable onset age and proximal weakness, leg cramps and contractures with limited flexion of fingers and toes [31, 32].

LGMD 1H (3p) is a novel subtype of dominant LGMD with yet unknown protein product described in an Italian family with variable onset age and severity, slowly progressive proximal weakness and calf hypertrophy [33].

\section{AUTOSOMAL RECESSIVE LGMD}

LGMD 2A (15q) is a very frequent disease worldwide, first decribed by Fardeau et al. in the Reunion Island, caused by mutations in CAPN 3 gene, encoding for calpain 3, a non-lysosomal calciumdependent cytosolic enzyme protein binding titin, involved in cytoskeletal remodeling and $\mathrm{IkB} \alpha / \mathrm{NF}-\mathrm{kB}$ pathway [34, 35]. Clinically, calpainopathy is characterized by early onset (between the ages 8-15, even later) of a symmetrical, selective atrophy of the proximal muscles with wasting of the musculature of the posterior compartment of the limbs, toe walking, scapular winging, early contractures of the elbows and calves and rarely calf hypertrophy. The intelligence is unaffected and heart dysfunctions are rare. LGMD 2A has a clinically wide variability both intra and interfamilial, with milder cases usually associated with missense mutations and more severe phenotypes with null mutations. CK level is high (still not as high as in dystrophinopathies, LGMD 2C-F or 2B), but reports of cases with normal serum $\mathrm{CK}$ suggest that a normal CK should not rule out a suspected LGMD $2 \mathrm{~A}[10,12]$.The life expectancy of the patients is close to normal. In the Romanian population, LGMD 2A is apparently the most frequent type of LGMD, with onset in childhood and middle adulthood, both in males and females. The patients $(\mathrm{n}=11)$ were diagnosed based on clinical and pathological means using IHC and WB techniques, but further genetic tests are needed to confirm and evaluate the mutational spectrum of CAPN 3 gene in our country.

LGMD 2B (2p) is associated with defects in the DYSF gene, encoding for the sarcolemmal protein dysferlin involved in membrane fusion, myogenesis or vesicle trafficking events. Dysferlinopathies include Miyoshi myopathy, a distal muscle disease affecting the gastrocnemius and LGMD type 2B [36, 37]. The disease has been identified in many countries, including Romania. The symptoms start in the late teens with distal or proximal weakness, in some of the patients with predominant anterior compartment distal weakness and inability to walk on tiptoes. A subacute presentation may be seen in $1 / 4$ of the patients simulating an inflamematory myopathy, both clinically and morphologically. The clinical picture is generally milder than in other AR-LGMDs and progression is slow. Calf hypertrophy can rarely be present, as well as rigid or lax spine. Early loss of Achilles tendon reflexes is also a disease feature. Serum CK level is always very high. Cardiac and respiratory muscles are not affected and intelligence is normal.

LGMD 2C-F (13q, 17q, 4q, 5q) are caused by mutations in the genes for, respectively, $\gamma, \alpha, \beta$ and $\delta$ sarcoglycans, a complex of dystrophinassociated glycoproteins located in the sarcolemma, providing support against physical damage and signaling functions for the membrane. Sarcoglycanopathies are relatively severe diseases with 
Duchenne-like clinical picture, early onset in childhood, high CK levels and frequent cardiac and respiratory complications. Milder cases are also seen, with a Becker-like phenotype [12, 38-40]. In Romania we identified three cases of $\gamma$ sarcoglycanopathy using IHC and WB.

LGMD 2G (17 q) is the result of mutations in the gene for telethonin, a sarcomeric protein localized at the Z- band, interacting with titin, with roles in myofiber assembly. This rare subtype of AR-LGMD is associated with early onset (in teens) of marked proximal weakness, loss of ambulation at the end of the third decade and sometimes cardiac complications. CK levels are 3-30 fold increased [41].

LGMD 2H (9q) has the genetic defect in TRIM 32, tripartite-motif containing gene 32. The TRIM 32 protein is a E3-ubiquitin ligase localized at the $\mathrm{Z}$ line, involved in labeling of proteins with ubiquitin for proteasome degradation. This form of LGMD, until now only found in Manitoba Hutterites in Canada, is a mild disease starting in the second or third decade of life with proximal slowly progressive weakness, without any cardiac involvement $[42,43]$.

LGMD 2 I (19 q) is caused by mutations in the fukutin-related protein gene FKRP and is allelic with severe forms of congenital muscular dystrophy with muscle hypertrophy and normal CNS (MDC 1C). FKRP is ubiquitous, located in the Golgi apparatus and associated with dystroglycan processing. In UK LGMD 2I is the most frequent type of LGMD, but still considered underdiagnosed. The spectrum of FKRP-related phenotypes is much more diverse than in other LGMD and the main differential diagnosis is dystrophinopathy, due to the similar pattern of predominantly proximal pelvifemoral weakness, calf hypertrophy, very high $\mathrm{CK}$ level and severe cardiac and respiratory complications. There are also asymptomatic patients until late adulthood [44-47].

LGMD 2J (2q) is due to rare homozygous mutations in the gene for titin, while heterozygous states lead to AD tibial dystrophy. Titin is a giant structural sarcomeric protein binding calpain and telethonin and playing an important mechanical, developmental and regulatory role. Clinically, the onset is in childhood with proximal weakness, anterior tibial wasting but no cardiac abnormalities [48].

LGMD 2K (9q) was described in Turkish families with mutations in POMT 1 gene and associates early mild proximal weakness, microcephaly, mental retardation and high CK level. POMT1 (protein O-mannosyltransferase 1) is an enzyme that catalyzes O-mannosylation of proteins $[5,49]$.

LGMD 2L (11p) is caused by mutations in ANO 5 encoding for anoctamin-5, a calciumactivated chloride channel with yet unknown function. In Central and Northern Europe, anoctaminopathy is apparently a frequent type of dystrophy with variable age of onset from 20-60 years, variable phenotype with asymmetric atrophy of quadriceps or in the form of nondysferlin Miyoshi myopathy, muscle pain, calf atrophy and inability to stand on toes. Asymptomatic patients with elevated CK were also described [50-62].

LGMD 2M (9q) is the result of mutations in the fukutin gene, the same involved in Fukuyama congenital muscular dystrophy, and have early age of onset, weakness of the leg, calf hypertrophy, high CK level, inflammatory changes on muscle biopsy and improvement with steroids [63, 64].

LGMD 2N (14 q) is the expression of mutations in the gene for POMT 2 protein (O- mannosyltransferase 2 protein), associated with endoplasmic reticulum. Mutations in POMT2 gene were also linked with a type of congenital muscular dystrophy with brain abnormalities. Other mutations are associated with a mild limb-girdle phenotype, elevated CK and absence of brain involvement. Defects in glycosylation of $\alpha$ dystroglycan cause several forms of LGMD [63, 65].

LGMD 20 (1p) due to POMGnT1 (O-linked mannose $\beta 12-\mathrm{N}$-acetylglucosaminyltransferase) gene mutation, had been described in a patient with proximal weakness, hypertrophy of calves and quadricceps, wasting of hamstrings, early loss of ambulation and high CK [66-68].

LGMD 2P (3p) is due to mutations in the gene for dystrophin-associated glycoprotein 1 (DAG 1), starts in the first decade with slowly progressive weakness and mental retardation [66, 69, 70].

LGMD 2Q (8q), caused by mutations in plectin, a sarcolemmal protein interacting with dystrophin and $\beta$ dystroglycan, lead to early stable generalized weakness, delayed walking, progressive course in teens, atrophy of muscles, very high CK level and loss of ambulation in adulthood [71].

LGMD 2R (2q), caused by recessive mutations in desmin have atrio-ventricular conduction blocks, proximal and facial weakness and respiratory involvement as main clinical features [72].

In LGMD 2S (4Q) mutations in transport protein particle complex 1, subunit 11 (TRAPPC11) cause a progressive proximal leg myopathy with early onset, scapular winging, fatigue, myalgia and involvement of the central nervous system $[73,74]$. 
Several other newly described forms are waiting to be added to the list of recessive LGMD: LGMD 2T, caused by mutations in the $G M P P B$ gene (GDP-mannose pyrophosphorylase B) associated with congenital muscular dystrophies due to hypoglycosylation of $\alpha$-dystroglycan and also with a new type of LGMD, described so far only in three patients with mental retardation and dystrophic finding on the muscle biopsy [75].

Another newely identified type is LGMD 2U, related to some particular alleles of the isoprenoid synthase domain containing gene and causing a severe Duchenne-like phenotype [76].

\section{MORPHOLOGICAL AND IMMUNOHISTOCHEMICAL ASPECTS IN LGMD}

The morphological picture in LGMD can be appreciated on muscle cryosections using histological, histochemical and enzyme histochemical techniques showing a more or less pronounced dystrophic pattern with a different amount of variation in the fibre size, round or polygonal atrophic and hypertrophic fibres, necrosis with or without phagocytosis, regeneration, splitting of fibres, lobulated fibres and fibrosis. In advanced stages, the muscle is partially or completely replaced by fat and connective tissue. The muscle biopsy must be made from a moderately affected muscle, thus require a prior thorough clinical examination and is better performed after image studies, to choose a muscle that is most imformative.

By itself the picture, useful for differential diagnosis with other muscular diseases, cannot differentiate between the various subtypes of LGMD, so a panel of antibodies is necessary for immunohistochemical and/or immunoblot assessment of frozen muscle tissue.
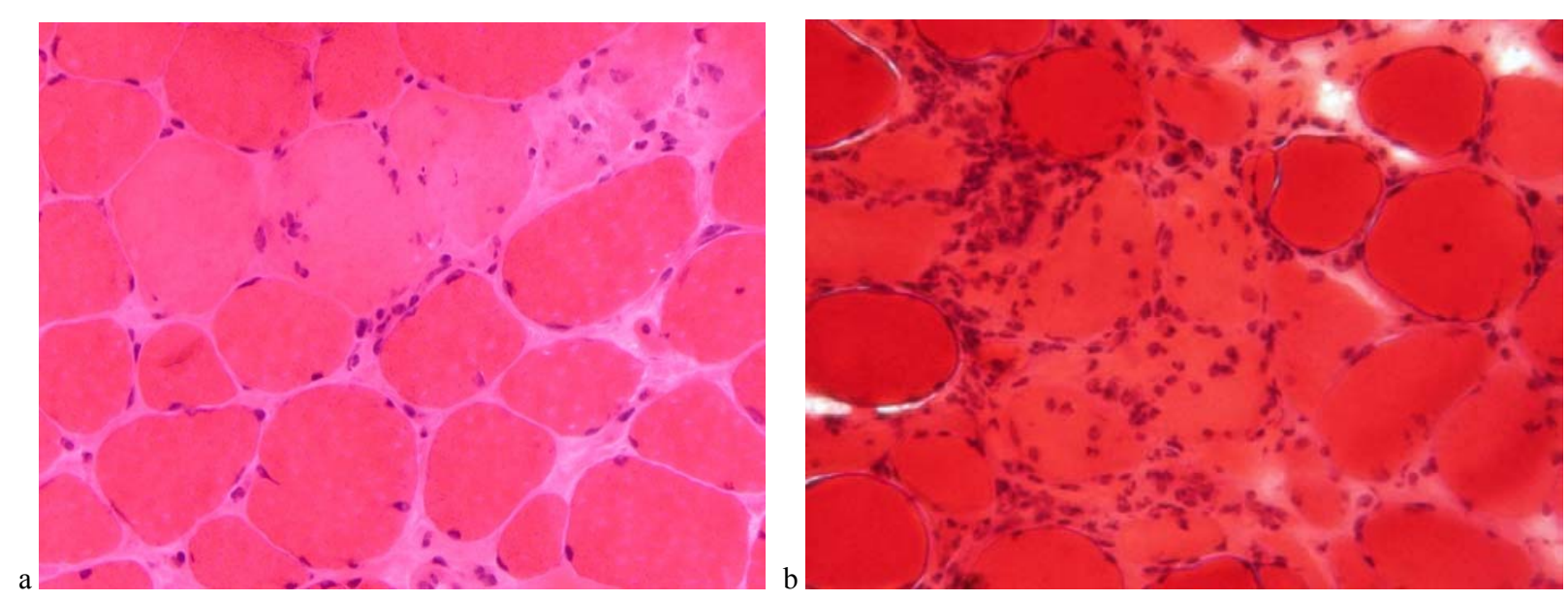

Figure 1. a Pale necrotic fibres in a case of LGMD 2A HE; b Necrosis with phagocytosis in a case of LGMD 2C. HE.
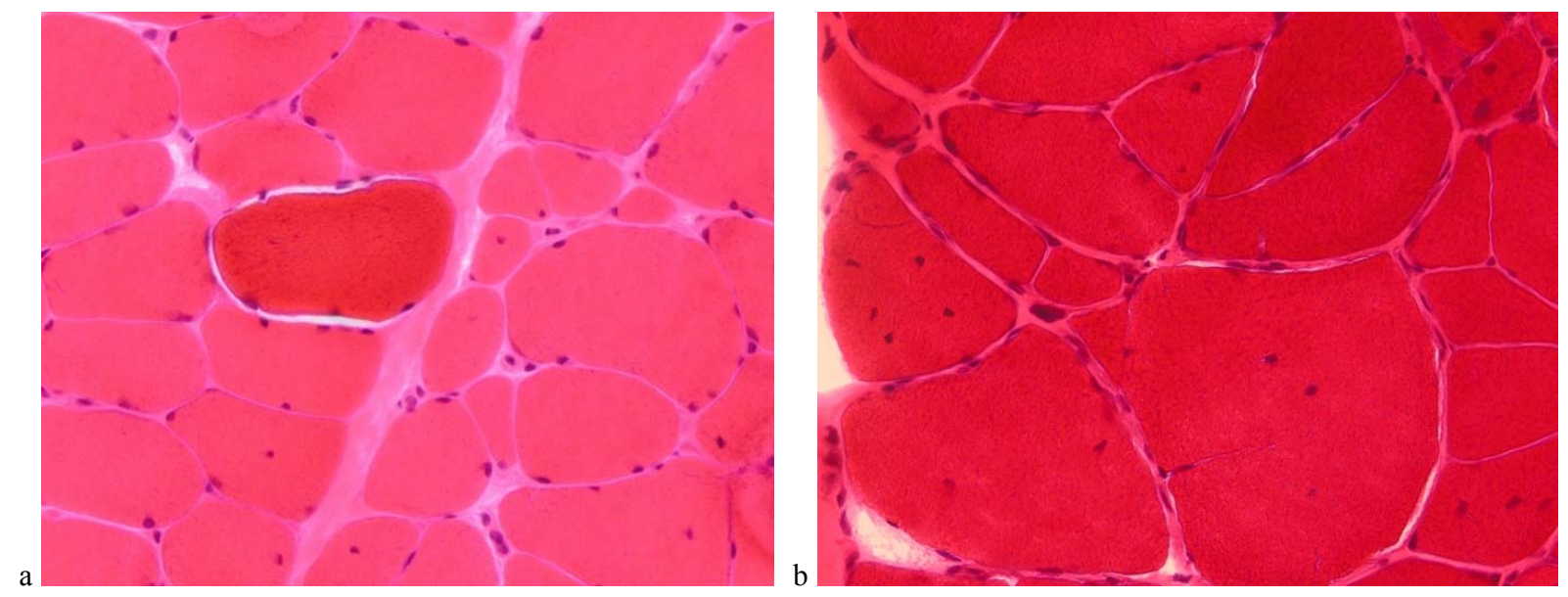

Figure 2. a.Variation in the fibre size and a hypercontracted fibre in LGMD 2A. HE; b. Splitting of fibres in a case of LGMD 2A. HE. 

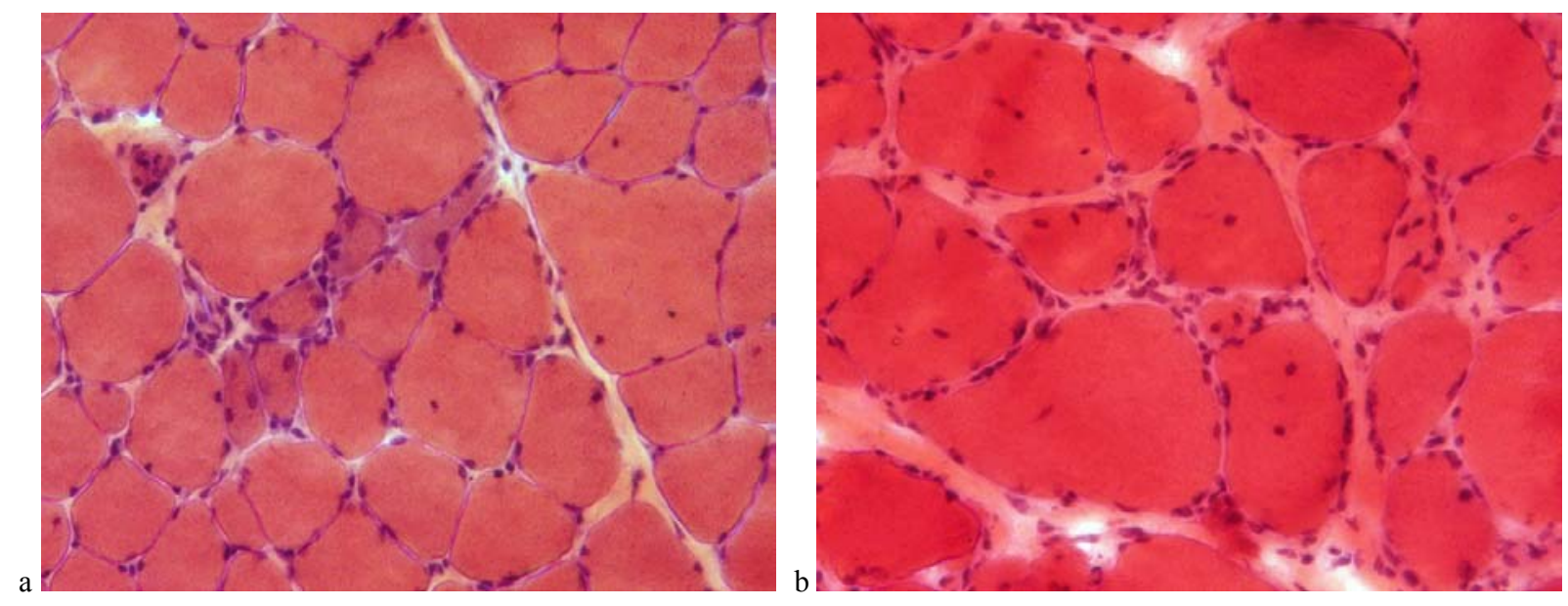

Figure 3. a. A group of basophilic regenerated fibres. HE;

b. Numerous internally located nuclei in LGMD 2C. HE.
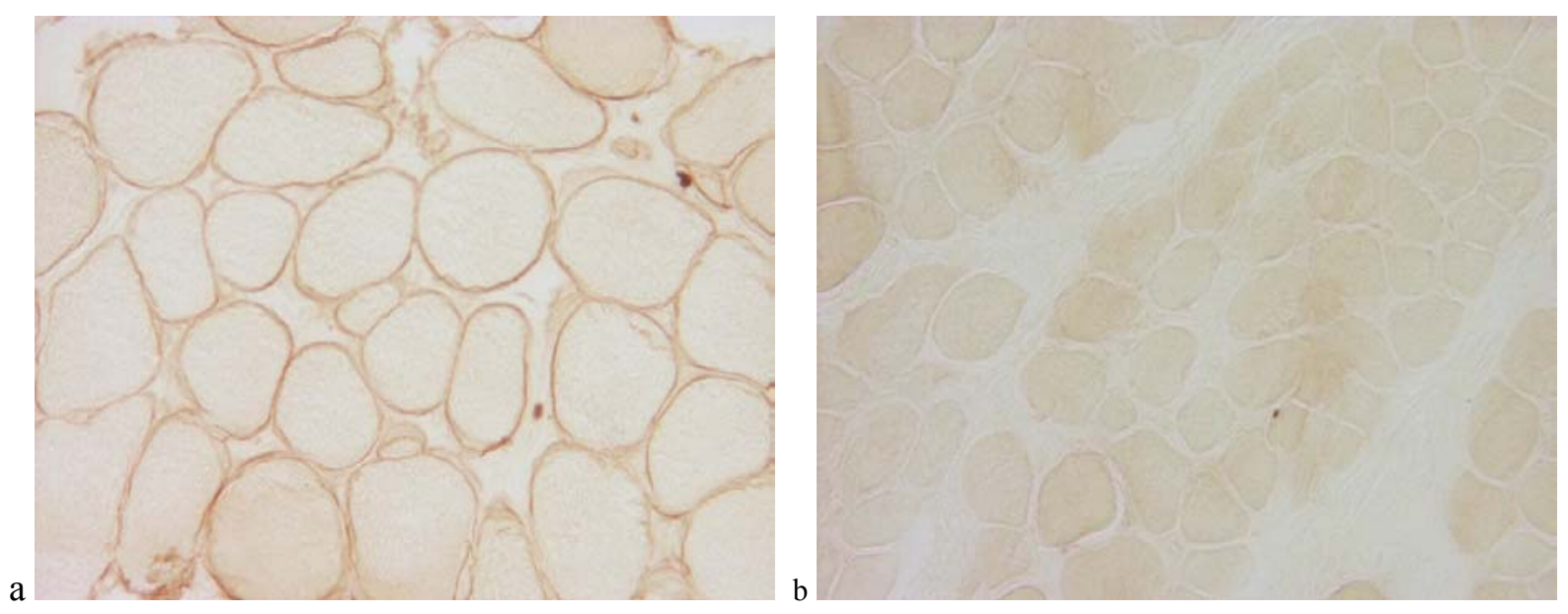

Figure 4. a. Normal immunolabeling of $\gamma$ SG in a case of LGMD 2A;

b. Absence of $\gamma$ SG on the sarcolemma in a case of LGMD 2C ( $\gamma$ SG, peroxidase).

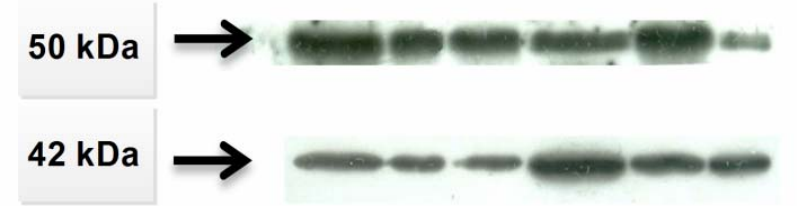

\section{alpha-Sarcoglycan}

\section{beta-Actin}

Figure 5. WB: $\alpha$ Sarcoglycan $(50 \mathrm{kDa})$ is present in all the muscular biopsies presented, showing a slight reduction in the 6-th lane. $\beta$-Actin is shown at the $42 \mathrm{kDa}$ molecular weight, as loading control.

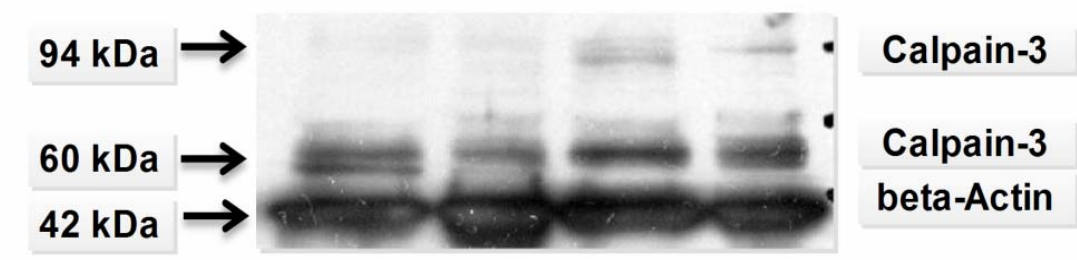

Figure 6. WB: Calpain-3 (monoclonal mouse antibody) pattern in different muscular biopsies, showing a reduction in lanes 1 and 2 for both Calpain-3 bands, at 94 and $60 \mathrm{kDa}$. On the same blot, $\beta$-Actin (polyclonal rabbit antibody) is shown at the $42 \mathrm{kDa}$, as loading control. 
Performance and interpretation of these tests require specialized and fully equipped laboratories, as not only primary, but also secondary reductions in protein expression can occur and may be difficult to interpret. This is particularly the case with the members of the dystrophin-associated glycoprotein complex. The protein analysis in close correlation with the clinical picture is a very important tool in directing further genetic tests and is considered a useful practice to analyze several proteins simultaneously $[3,77]$.

Table I

Morphological aspects in dominant L GMD

\begin{tabular}{|c|c|c|c|}
\hline $\begin{array}{c}\text { Type of } \\
\text { LGMD }\end{array}$ & Protein & $\begin{array}{c}\text { Characteristic } \\
\text { pathological features }\end{array}$ & IHC /WB features \\
\hline 1A & Myotilin & $\begin{array}{c}\text { D, Rimmed vacuoles with or } \\
\text { without inclusions }\end{array}$ & $\begin{array}{c}\text { IHC: Protein aggregates } \\
\text { Secondary laminin- } \gamma \text { reduction }\end{array}$ \\
\hline 1B & Lamin A/C & $\begin{array}{c}\text { Myopathic, Rimmed vacuoles, } \\
\text { inclusions }\end{array}$ & $\begin{array}{c}\text { Lamin A/C normal expression } \\
\text { Secondary laminin- } \beta \text { reduction }\end{array}$ \\
\hline 1C & Caveolin 3 & $\begin{array}{c}\text { D, on EM loss of caveolae at the } \\
\text { sarcolemma }\end{array}$ & $\begin{array}{c}\text { IHC, WB: Absence/reduction of caveolin 3 } \\
\text { Secondary reduction of dysferlin }\end{array}$ \\
\hline 1D & DNAJB6 & $\begin{array}{c}\text { D, Rimmed vacuoles, eosinophilic } \\
\text { cytoplasmic body }\end{array}$ & - \\
\hline 1E & Desmin & $\begin{array}{c}\text { Granulofilamentous inclusions - } \\
\text { subsarcolemmal and perinuclear }\end{array}$ & - \\
\hline 1F & Transportin 3 & D, Rimmed vacuoles & Increased desmin expression - some fibers \\
\hline 1G & HRNPDL & $\begin{array}{c}\text { D, Rimmed vacuoles, } \\
\text { denervation-like }\end{array}$ & Vacuoles stain with sarcoglycans and \\
& & dystrophin \\
\hline 1H & ? & D, mitochondrial abnormalities & \\
\hline
\end{tabular}

Table II

Morphological aspects in recessive LGMD

\begin{tabular}{|c|c|c|c|}
\hline $\begin{array}{l}\text { Type of } \\
\text { LGMD }\end{array}$ & Protein & $\begin{array}{c}\text { Characteristic } \\
\text { pathological features }\end{array}$ & IHC /WB features \\
\hline $\mathbf{2 A}$ & Calpain 3 & $\begin{array}{l}\text { D, Lobulated/trabeculated fibres, } \\
\text { eosinophils, neurogenic-like atrophy }\end{array}$ & $\begin{array}{l}\text { WB only: reduction/absence of calpain } 3 \text {, may be normal } \\
\text { Secondary reduction of dysferlin in } 1 / 2 \text { of the cases }\end{array}$ \\
\hline 2B & Dysferlin & $\begin{array}{l}\mathrm{D} \text {, sometimes inflammatory infiltrates } \\
\text { T-cells and macrophages }\end{array}$ & $\begin{array}{l}\text { Complete absence or reduction of dysferlin } \\
\text { Secondary reduction of calpain } 3 \text { and/or caveolin } 3 \text {, } \\
\text { aquaporin }-4\end{array}$ \\
\hline 2C & $\gamma$ Sarcoglycan & $\mathrm{D}$ & Absence of $\gamma$ SG, reduction of the other SG \\
\hline 2D & $\alpha$ Sarcoglycan & $\mathrm{D}$ & Absence of $\alpha \mathrm{SG}$, reduction of the other SG \\
\hline $2 \mathbf{E}$ & $\beta$ Sarcoglycan & $\mathrm{D}$ & Absence of $\beta$ SG, reduction of the other SG \\
\hline $2 \mathbf{F}$ & o Sarcoglycan & $\mathrm{D}$ & Absence of $\delta$ SG, reduction of the other SG \\
\hline $2 G$ & Telethonin & $\mathrm{D}$, rimmed vacuoles, lobulated fibres & Absence of telethonin \\
\hline $2 \mathbf{2 H}$ & TRIM 32 & mild D & \\
\hline 2I & FKRP & $\mathrm{D}$, inflammatory infiltrates & Reduction of $\alpha$ dystroglycan, merosin \\
\hline 2J & Titin & Myopathic & WB: Reduction of calpain 3, C-terminal titin fragments \\
\hline $2 K$ & POMT 1 & Variation in the fiber size & - \\
\hline $2 \mathbf{L}$ & Anoctamin 5 & D, inflammation, amyloid & Reduction of dystrophin, calpain 3 in some cases \\
\hline $2 \mathrm{M}$ & Fukutin & D, inflammation & Reduction of $\alpha$ dystroglycan, merosin \\
\hline $2 \mathbf{N}$ & POMT2 & $\mathrm{D}$ & Reduction of $\alpha$ dystroglycan \\
\hline 20 & POMGnT1 & $\mathrm{D}$ & $\alpha$ dystroglycan present, variable intensity \\
\hline $2 \mathbf{P}$ & DAG 1 & $\mathrm{D}$ & Reduction of $\alpha$ dystroglycan \\
\hline $2 Q$ & Plectin & $\mathrm{D}$ & Absence/reduction of sarcolemmal plectin labeling \\
\hline 2R & Desmin & $\begin{array}{l}\text { Mallory body- like } \\
\text { inclusions/subsarcolemmal deposits }\end{array}$ & Dystrophin and desmin accumulation \\
\hline $2 \mathrm{~S}$ & TRAPPC11 & Myopathic & D - dystrophic picture- \\
\hline
\end{tabular}




\section{DIFFERENTIAL DIAGNOSIS IN LGMD}

The differential diagnosis list in LGMD is both clinically and morphologically very broad and include more common and even potentially treatable diseases in internal medicine and rheumatology. Another important and challenging aspect is to differentiate between the numerous subtypes of LGMD, through clinical examinations, MRI imaging that can highlight preferential involvement of certain muscle groups with sparing of others depending on the type of dystrophy, morphological assessment of the biopsy, IHC and WB and genetic tests (Table III).

Table III

Differential diagnosis in LGMD

\begin{tabular}{|l|l|}
\hline \multicolumn{1}{|c|}{ Disease } & \multicolumn{1}{c|}{ Specific aspects } \\
\hline $\begin{array}{l}\text { Inflammatory myopathies (polymyositis, } \\
\text { dermatomyositis, inclusion-body myositis-IBM) }\end{array}$ & $\begin{array}{l}\text { More rapid evolution, more generalized weakness, spontaneous activity on } \\
\text { EMG, inflammatory and other characteristic aspects on the muscle biopsy, } \\
\text { serological tests, responsivity to immunosuppressive therapy }\end{array}$ \\
\hline $\begin{array}{l}\text { Dystrophinopathies (Duchenne, Becker, female } \\
\text { manifesting carriers) }\end{array}$ & $\begin{array}{l}\text { Pattern of inheritance } \\
\text { Dystrophin gene mutations on DNA analysis } \\
\text { Dystrophin expression abnormalities in muscle tissue using IHC and/or WB }\end{array}$ \\
\hline Facioscapulohumeral dystrophy & $\begin{array}{l}\text { Involvement of face, scapular, lower abdominal muscles, lumbar } \\
\text { hyperlordosis, distal lower limb weakness } \\
\text { Genetic tests available }\end{array}$ \\
\hline $\begin{array}{l}\text { Congenital myopathies (central core /multicore } \\
\text { disease, nemaline rod myopathy, centronuclear, } \\
\text { desmin myopathy, congenital fiber type } \\
\text { disproportion) }\end{array}$ & $\begin{array}{l}\text { Early onset usually } \\
\text { Slowly progressive or relatively static weakness } \\
\text { Characteristic histological and histochemical bioptical aspects and specific } \\
\text { genetic tests }\end{array}$ \\
\hline Glycogenosis and lipid myopathies & $\begin{array}{l}\text { Histological, histochemical, enzyme histochemical features on muscle } \\
\text { biopsy, } \alpha \text { glucosidase enzyme activity }\end{array}$ \\
\hline Mitochondrial myopathies & $\begin{array}{l}\text { Multisystemic involvement, morphological and biochemical characteristics, } \\
\text { specific molecular tests }\end{array}$ \\
\hline Spinal muscular atrophies & $\begin{array}{l}\text { More diffuse pattern of weakness, fasciculations, extremity tremor, } \\
\text { neurogenic EMG and specific muscle biopsy aspects, normal CK, molecular } \\
\text { tests }\end{array}$ \\
\hline Endinical context, different age groups \\
\hline Emery-Dreifuss muscular dystrophy & $\begin{array}{l}\text { X-linked, early contractures, cardiac involvement, humeroperoneal } \\
\text { weakness }\end{array}$ \\
\hline Myotonic dystrophies (types 1 and 2) & $\begin{array}{l}\text { Myotonia, facial and jaw weakness, ptosis in DM1 } \\
\text { Distal weakness, myalgia, tremor, normal CK in DM2 }\end{array}$ \\
\hline syndromes & $\begin{array}{l}\text { Fluctuating weakness and ptosis } \\
\text { Neurophysiological tests, serum anti-acetylcholine and anti- Musk } \\
\text { antibodies }\end{array}$ \\
\hline
\end{tabular}

\section{CONCLUSIONS}

Due to increasing complexity of diagnosis and management in LGMD, nowadays the main tasks are complete genotype-phenotype correlations in various populations, through concerted efforts involving many centres around the world and specialists in different fields which will lead to a better understanding of the molecular mechanisms underlying these disorders. It is assumed that these studies will be followed by the discovery and development of targeted therapies. An aspect of equal importance is also to increase awareness of physicians in different specialties on the existence and diversity of these diseases.

Distrofiile musculare forma centurilor reprezintă un grup de afecțiuni extrem de heterogen şi în rapidă expansiune, caracterizate prin deficit muscular pelvin, scapular şi la nivelul trunchiului, fără afectarea musculaturii faciale şi distale în majoritatea subtipurilor de boală, cu debut în copilărie sau în perioada adultă la ambele sexe şi cu severitate clinică extrem de variabilă de la fenotipuri uşoare la forme severe, unele asociate cu afectare cardio-pulmonară şi extrascheletală şi niveluri foarte crescute ale creatin-kinazei serice. In ultimii ani s-au înregistrat progrese uriaşe ale diferitelor metode de identificare şi au fost descoperite noi 
entități distincte. Totuşi, încă nu este suficient de clar de ce există o afectare selectivă a unor grupe musculare cu lipsa de afectare a altora în diferitele subtipuri de boală şi de ce tablouri clinice similare se asociază cu gene şi mutații diferite, în timp ce aceleaşi gene şi chiar aceleaşi mutații se pot asocia cu fenotipuri foarte variate. In acest review sintetizăm principalele aspecte de diagnostic pozitiv şi diferențial al distrofiilor musculare forma centurilor.

Acknowledgement: This paper is supported by the Sectoral Operational Programme Human Resources Development (SOP HRD), financed from the European Social Fund and by the Romanian Government under the contract number POSDRU/159/1.5/S/137390

Corresponding author: Alexandra Bastian, “Colentina” University Hospital, Department of Pathology,

19, Ştefan cel Mare Str., Sector 2, 020125

Bucharest, Romania, Tel.: +40213173245, Fax: +40213165512

E-mail: aleca.bastian@yahoo.com

\section{REFERENCES}

1. WICKLUND MP, KISSEL JT. The limb-girdle muscular dystrophies. Neurol Clin 2014; 32(3): 729-49.

2. WALTON J, NATRASS F. On the classification, natural history and treatment of the myopathies. Brain. 1954; 77:169-231.

3. BARESI R. From proteins to genes: immunoanalysis in the diagnosis of muscular dystrophies. Skeletal Muscle. $2011 ; 1: 24$.

4. MAHMOOD O, JIANG XM. Limb-girdle muscular dystrophies: Where next after six decades from the first proposal. Mol Med Rep, 2014; 9(5): 1515-1532.

5. NIGRO V, SAVARESE M. Genetic basis of limb-girdle muscular dystrophies: the 2014 update. Acta Myologica 2014; 32: 1-12.

6. COTTA A, CARVALHO E, LOPES DA-CUNHA A, et al. Common recessive limb girdle muscular dystrophies differential diagnosis: why and how? Arq Neuropsiquiatr, 2014; 72(9): 721-734.

7. NORWOOD FL, HARLING C, CHINNERY PF, EAGLE M, BUSHBY K, STRAUB V. Prevalence of genetic muscle disease in Northern England: in-depth analysis of a muscle clinic population. Brain. 2009; 132: 3175-3186.

8. GOMEZ-DIAZ B, ROSAS-VARGAS H, ROQUE-RAMIREZ B, et al. Immunodetection analysis of muscular dystrophies in Mexico. Muscle Nerve. 2012; 45: 338-345.

9. DINIZ G, ERYAŞAR G, TÜRE S, et al. A regional panorama of dysferlinopathies. Turk Patoloji Derg. 2012; 28: 259-265.

10. FANIN M, NASCIMBENI AC, FULIZIO L, et al. The frequency of limb girdle muscular dystrophy $2 A$ in northeastern Italy. Neuromuscul Disord 2005; 15:218-24.

11. STEHLÍKOVÁ K, SKÁLOVÁ D, ZÍDKOVÁ J, MRÁZOVÁL, MAZANEC R, VOHANKA S, HABERLOVA J, HERMANOVA M, ZAMECNIK J, SOUCEK O, OŠLEJŠKOVÁ H, DVOŘÁČKOVÁ N, SOLAROVA P, FAJKUSOVÁ L. Autosomal recessive limb-girdle muscular dystrophies in the Czech Republic. BMC Neurology 2014, 14:154.

12. ZATZ M, DE PAULA F, STARLING A, VAINZOF M. The 10 autosomal recessive limb-girdle muscular dystrophies. Neuromuscular disorders, 2003; 13: 532-544.

13. PENISSON-BESNIER I, HACKMAN P, SUOMINEN T, et al. Myopathies caused by homozygous titin mutations: limb-girdle muscular dystrophy $2 J$ and variations of phenotype. J Neurol Neurosurg Psychiatry 2010; 81:1200-2.

14. HALLIDAY W, GREENBERG CR, WROGEMANN K, et al. Genetic heterogeneity of limb girdle muscular dystrophy in Manitoba Hutterites. Am J Hum Genet 1998; 63 (Suppl): A 392.

15. SHOKEIR MH, KOBRINSKY NL. Autosomal recessive muscular dystrophy in Manitoba Hutterites. Clin Genet. 1976; 9(2): 197-202.

16. WEILER T, GREENBERG CR, ZELINSKI T, et al. Limb Girdle Muscular Dystrophy in Manitoba Hutterites maps to chromosome region 9q31-q33: evidence for another LGMD locus. Am J Hum Genet. 1998; 63: 140-7.

17. REILICH P, KRAUSE S, SCHRAMM N, et al. A novel mutation in the myotilin gene (MYOT) causes a severe form of limb girdle muscular dystrophy $1 A$ (LGMD1A). J Neurol 2011; 258:1437-44.

18. HAUSER MA, HORRIGAN SK, SALMIKANGAS P, et al. Myotilin is mutated in limb girdle muscular dystrophy 1A. Hum Mol Genet, 2000; 9:2141-7.

19. SALMIKANGAS P, VAN DER VEN PF, LALOWSKI M, TAIVAINEN A, ZHAO F, SUILA H, SCHRÖDER R, LAPPALAINEN P, FÜRST DO, CARPÉN O. Myotilin, the limb-girdle muscular dystrophy 1A (LGMD1A) protein, cross-links actin filaments and controls sarcomere assembly. Hum Mol Genet. 2003; 12(2): 189-203.

20. MUCHIR A, BONNE G, VAN DER KOOI AJ, et al. Identification of mutations in the gene encoding lamins A/C in autosomal dominant limb-girdle muscular dystrophy with atrioventricular conduction disturbances (LGMD1B). Hum Mol Genet 2000; 9:1453-9.

21. LAVAL SH, BUSHBY KM. Limb-girdle muscular dystrophies-from genetics to molecular pathology. Neuropathol Appl Neurobiol. 2004; 30(2):91-105.

22. POLITANO L, CARBONI N, MADEJ-PILARCZYK A, et al. Advances in basic and clinical research in laminopathies. Acta Myol, 2013; 32:18-22.

23. COUCHOUX H, BICHRAOUI H, CHOUABE C, ALTAFAJ X, BONVALLET R, ALLARD B, RONJAT M, BERTHIER C. Caveolin-3 is a direct molecular partner of the Cav 1.1 subunit of the skeletal muscle L-type calcium channel. The International Journal of Biochemistry \& Cell Biology, 2011; 43 (5): 713-720. 
24. GAZZERRO E, SOTGIA F, BRUNO C, LISANTI MP, MINETTI C. Caveolinopathies: from the biology of caveolin-3 to human diseases. European Journal of Human Genetics. 2010; 18: 137-145.

25. LO HP, BERTINI E, MIRABELLA M, DOMAZETOVSKA A, DALE RC, PETRINI S, D’AMICO A, VALENTE EM, BARRESI R, ROBERTS M, TOZZI G, TASCA G, COOPER ST, et al. Mosaic caveolin-3 expression in acquired rippling muscle disease without evidence of myasthenia gravis or acetylcholine receptor autoantibodies. Neuromuscular Disorders, 2011; 21 (3): 194-203.

26. MINETTI C, SOTGIA F, BRUNO C, SCARTEZZINI P, BRODA P, BADO M, MASETTI E, MAZZOCCO M, EGEO A, DONATI M A, VOLONTÉ D, GALBIATI F, CORDONE G, et al. Mutations in the caveolin-3 gene cause autosomal dominant limb-girdle muscular dystrophy. Nature Genetics, 1998; 18: 365-368.

27. CARBONE I, BRUNO C, SOTGIA F, BADO M, BRODA P, MASETTI E, PANELLA A, ZARA F, BRICARELLI FD, CORDONE G, LISANTI MP, MINETTI C. Mutation in the CAV3 gene causes partial caveolin-3 deficiency and hyperCKemia. Neurology.2000; 54(6):1373-6.

28. MERLINI L, CARBONE I, CAPANNI C, SABATELLI P, TORTORELLI S, LISANTI MP, BRUNO C, MINETTI C. Familial isolated hyperCKaemia associated with a new mutation in the caveolin-3 (CAV-3) gene. J Neurol Neurosurg Psychiatry. 2002; 73(1):65-7.

29. WOODMAN SE, SOTGIA F, GALBIATI F, MINETTI C, LISANTI MP. Caveolinopathies: mutations in caveolin-3 cause four distinct autosomal dominant muscle diseases. Neurology.2004 ; 62(4): 538-43.

30. PETERLE E, FANIN M, SEMPLICINI C, et al. Clinical phenotype, muscle MRI and muscle pathology of LGMD1F. J Neurol, 2013; 260:2033-41.

31. VIEIRA NM, NASLAVSKY MS, LICINIO L, et al. A defect in the RNAprocessing protein HNRPDL causes limb-girdle muscular dystrophylG (LGMD1G). Hum Mol Genet 2014. [Epub ahead of print]

32. STARLING A, KOK F, PASSOS-BUENO MR, et al. A new form of autosomal dominant limb-girdle muscular dystrophy (LGMD1G) with progressive fingers and toes flexion limitation maps to chromosome 4p21. Eur J Hum Genet 2004; 12: $1033-40$.

33. BISCEGLIA L, ZOCCOLELLA S, TORRACO A, et al. A new locus on 3p23-p25 for an autosomal-dominant limb-girdle muscular dystrophy, LGMD1H. Eur J Hum Genet 2010; 18: 636-41.

34. FARDEAU M, HILLAIRE D, MIGNARD C, FEINGOLD N, FEINGOLD J, MIGNARD D, DE UBEDA B, COLLIN H, TOME FM, RICHARD I, BECKMANN J. Juvenile limb-girdle muscular dystrophy: clinical, histopathological and genetic data from a small community living in the Reunion Island. Brain 1996; 119: 295-308.

35. PATHAK P, SHARMA MC, SARKAR C, et al. Limb-girdle muscular dystrophy type $2 A$ in India: a study based on semiquantitative protein analysis, with clinical and histopathological correlation. Neurol India, 2010; 58: 549-54.

36. WEILER T, BASHIR R, ANDERSON LV, et al. Identical mutation in patients with limb girdle muscular dystrophy type $2 B$ or Miyoshi myopathy suggests a role for modifier gene (s). Hum Mol Genet, 1999; 8:871-7.

37. CACCIOTTOLO M, NUMITONE G, AURINO S, et al. Muscular dystrophy with marked Dysferlin deficiency is consistently caused by primary dysferlin gene mutations. Eur J Hum Genet. 2011; 19:974-80.

38. NOGUCHI S, MCNALLY EM, BEN OTHMANE K, et al. Mutations in the dystrophin-associated protein gamma-sarcoglycan in chromosome13 muscular dystrophy. Science. 1995; 270:819-22.

39. LIM LE, DUCLOS F, BROUX O, et al. Beta-sarcoglycan: characterization and role in limb-girdle muscular dystrophy linked to $4 q 12$. Nat Genet. 1995; 11:257-65.

40. ROBERDS SL, LETURCQ F, ALLAMAND V, et al. Missense mutations in the adhalin gene linked to autosomal recessive muscular dystrophy. Cell 1994; 78:625-33.

41. MOREIRA ES, WILTSHIRE TJ, FAULKNER G, et al. Limb-girdle muscular dystrophy type $2 G$ is caused by mutations in the gene encoding the sarcomeric protein telethonin. Nat Genet 2000; 24:163-6.

42. LOCKE M, TINSLEY CL, BENSON MA, et al. TRIM32 is an E3 ubiquitin ligase for dysbindin. Hum Mol Genet 2009; 18:2344-58.

43. FROSK P, WEILER T, NYLEN E, et al. Limb-girdle muscular dystrophy type $2 H$ associated with mutation in TRIM32, a putative E3-ubiquitin-ligase gene. Am J Hum Genet 2002; 70: 663-72.

44. BROWN SC, TORELLI S, BROCKINGTON M, YUVA Y, JIMENEZ C, FENG L, ANDERSON L, UGO I, KROGER S, BUSHBY K, VOIT T, SEWRY C, MUNTONI F. Abnormalities in alpha-dystroglycan expression in MDC1C and LGMD2I muscular dystrophies, American Journal of Pathology, 2004, 164 (2):727-37.

45. LIANG W-C, HAYASHI YK, OGAWA M, WANG C-H, HUANG W-T, NISHINO I, JONG Y-J. Limb-girdle muscular dystrophy type 2I is not rare in Taiwan. Neuromuscular Disorders, 2013, 23 (8): 675-681.

46. BROCKINGTON M, BLAKE DJ, PRANDINI P, et al. Mutations in the fukutin-related protein gene (FKRP) cause a form of congenital muscular dystrophy with secondary laminin alpha2 deficiency and abnormal glycosylation of alpha-dystroglycan. Am J Hum Genet, 2001; 69:1198-209.

47. MERCURI E, BROCKINGTON M, STRAUB V, et al. Phenotypic spectrum associated with mutations in the fukutin-related protein gene. AnnNeurol, 2003; 53:537-42.

48. GERULL B, GRAMLICH M, ATHERTON J, et al. Mutations of TTN, encoding the giant muscle filament titin, cause familial dilated cardiomyopathy. Nat Genet 2002; 30:201-4.

49. CHONG YK, KWAN MA LC, LO KL, LAI LEE CK, MAK CM, CHI KAN AN, LAM CW. Dystroglycanopathy with two novel POMT1 mutations in a Chinese boy with developmental delay and muscular dystrophy. European Journal of Paediatric Neurology, 2014 [Epub ahead of print].

50. BEHIN A, LETURCQ F, COSSÉE M, WAHBI K, DEBURGRAVE N, BÉCANE H-M, CARLIER R-Y, LAFORÊT P, STOJKOVIC T, CARLIER P, EYMARD B. Anoctamin 5 myopathy: More patients, more phenotypes. Journal of the Neurological Sciences, 2013, 333 (Suppl. 1): e47. 
51. BOLDUC V, MARLOW G, BOYCOTT KM, SALEKI K, INOUE H, KROON J, ITAKURA M, ROBITAILLE Y, PARENT L, BAAS F, et al. Recessive Mutations in the Putative Calcium-Activated Chloride Channel Anoctamin 5 Cause Proximal LGMD2L and Distal MMD3 Muscular Dystrophies. The American Journal of Human Genetics. 2010; 86:213-221.

52. BOUQUET F, COSSEE M, BEHIN A, DEBURGRAVE N, ROMERO N, LETURCQ F, EYMARD B. Miyoshi-like distal myopathy with mutations in anoctamin 5 gene (Myopathie de type Miyoshi associée à des mutations du gène de l'anoctamine 5). Revue Neurologique. 2012; 168 (2): 135-141.

53. HICKS D, SARKOZY A, MUELAS N, KÖEHLER K, HUEBNER A, HUDSON G, CHINNERY PF, BARRESI R, EAGLE M, et al. A founder mutation in Anoctamin 5 is a major cause of limb girdle muscular dystrophy. Brain. 2011; 134 (1): 171-182.

54. LITTLE A, MCKEEVER P, GRUIS K. Novel mutations in the anoctamin 5 gene (ANO5) associated with limb-girdle muscular dystrophy 2L. Muscle \& Nerve, 2013; 47 (2): 287-291.

55. MAGRI F, DEL BO R, D'ANGELO MG, SCIACCO M, GANDOSSINI S, GOVONI A, NAPOLI L, CISCATO P, et al. Frequency and characterisation of anoctamin 5 mutations in a cohort of Italian limb-girdle muscular dystrophy patients. Neuromuscular Disorders, 2012; 22 (11): 934-943.

56. MAHJNEH I, JAISWAL J, LAMMINEN A, SOMER M, MARLOW G, KIURU-ENARI S, BASHIR R. A new distal myopathy with mutation in anoctamin 5. Neuromuscular Disorders, 2010; 20 (12): 791-795.

57. RAJ JOSHI P, GLÄSER D, DREßEL C, KRESS W, WEIS J, DESCHAUER M. Anoctamin 5 muscular dystrophy associated with a silent p.Leu1 15Leu mutation resulting in exon skipping. Neuromuscular Disorders, 2014; 24 (1): 43-47.

58. SARKOZY A, HICKS D, HUDSON J, LAVAL SH, BARRESI R, HILTON-JONES D, DESCHAUER M, HARRIS E, et al. ANO5 Gene Analysis in a Large Cohort of Patients with Anoctaminopathy: Confirmation of Male Prevalence and High Occurrence of the Common Exon 5 Gene Mutation. Human Mutation. 2013; 34 (8): 1111-1118.

59. SCHESSL J, KRESS W, SCHOSER B. Novel ANO5 mutations causing hyper-CK-emia, limb girdle muscular weakness and Miyoshi type of muscular dystrophy, 2012; Muscle \& Nerve, 45 (5): 740-742.

60. WAHL CM, VAN GHELUE M, ARNTZEN KA, HALVORSEN H, INGEBRIGTSEN M, SKOGSTAD A, HESTHOLM B, LØSETH S, MELLGREN SI, RASMUSSEN F, LINDAHL S, JONSRUD C. Mutations in anoctamin 5 in limb girdle muscular dystrophy in Norway: Phenotypic variability and mutation spectrum. Journal of the Neurological Sciences, 2013; 333 (SUPPL. 1): E444.

61. WITTING N, DUNO M, PETRI H, KRAG T, BUNDGAARD H, KOBER L, VISSING J. Anoctamin 5 muscular dystrophy in Denmark: prevalence, genotypes, phenotypes, cardiac findings, and muscle protein expression. Journal of Neurology, 2013; 260 (8): 2084-2093.

62. TIAN Y, SCHREIBER R, KUNZELMANN K. Anoctamins are a family of Ca2+-activated Cl-channels. J Cell Sci; 125:4991-8.

63. MERCURI E, MESSINA S, BRUNO C, et al. Congenital muscular dystrophies with defective glycosylation of dystroglycan: a population study. Neurology, 2009; 72: 1802-9.

64. PUCKETT RL, MOORE SA, WINDER TL, et al. Further evidence of Fukutin mutations as a cause of childhood onset limbgirdle muscular dystrophy without mental retardation. Neuromuscul Disord, 2009; 19:352-6.

65. BIANCHERI R, FALACE A, TESSA A, et al. POMT2 gene mutation in limb-girdle muscular dystrophy with inflammatory changes. Biochem Biophys Res Commun, 2007; 363:1033-7.

66. PANE M, MESSINA S, VASCO G, FOLEY AR, MORANDI L, PEGORARO E, MONGINI T, D'AMICO A, BIANCO F, LOMBARDO ME, SCALISE R, BRUNO C, BERARDINELLI A, et al. Respiratory and cardiac function in congenital muscular dystrophies with alpha dystroglycan deficiency. Neuromuscular Disorders, 2012; 22 (8): 685-689.

67. CLEMENT EM, GODFREY C, TAN J, et al. Mild POMGNT1 mutations underlie a novel limb-girdle muscular dystrophy variant. Arch Neurol, 2008; 65:137-41.

68. RADUCU M, BAETS J, FANO O, et al. Promoter alteration causes transcriptional repression of the POMGNT1 gene in limbgirdle muscular dystrophy type 20. Eur J Hum Genet, 2012.

69. GODFREY C, FOLEY AR, CLEMENT E, MUNTONI F. Dystroglycanopathies: coming into focus, Current Opinion in Genetics \& Development. 2011; 21 (3): 278-285.

70. HARA Y, BALCI-HAYTA B, YOSHIDA-MORIGUCHI T, KANAGAWA M, BELTRÁN-VALERO DE BERNABÉ D, GÜNDEŞLI H, WILLER T, SATZ JS, CRAWFORD RW, et al. A Dystroglycan Mutation Associated with Limb-Girdle Muscular Dystrophy. New Engl. J. Med. 2011; 364(10): 939-946.

71. GUNDESLI H, TALIM B, KORKUSUZ P, et al. Mutation in exon If of PLEC, leading to disruption of plectin isoform $1 f$, causes autosomal-recessive limb-girdle muscular dystrophy. Am J Hum Genet 2010; 87:834-41.

72. CETIN N, BALCI-HAYTA B, GUNDESLI H, et al. A novel desmin mutation leading to autosomal recessive limb-girdle muscular dystrophy: distinct histopathological outcomes compared with desminopathies. J Med Genet 2013; 50:437-43.

73. BOGERSHAUSEN N, SHAHRZAD N, CHONG JX, et al. Recessive TRAPPC11 mutations cause a disease spectrum of limb girdle musculardystrophy and myopathy with movement disorder and intellectual disability. Am J Hum Genet; 93:181-90. 87:834-41.

74. SCRIVENS PJ, SHAHRZAD N, MOORES A, et al. TRAPPC2L is a novel, highly conserved TRAPP-interacting protein. Traffic 2009; 10:724-36.

75. CARSS KJ, STEVENS E, FOLEY AR, CIRAK, RIEMERSMA M, TORELLI S, HOISCHEN A, WILLER T, VAN SCHERPENZEEL M, MOORE SA, et al. Mutations in GDP-Mannose Pyrophosphorylase B Cause Congenital and LimbGirdle Muscular Dystrophies Associated with Hypoglycosylation of $\alpha$-Dystroglycan. The American Journal of Human Genetics. 2013; 93 (1): 29-41.

76. CIRAK S, FOLEY AR, HERRMANN R, WILLER T, YAU S, STEVENS E, TORELLI S, BRODD L, KAMYNINA A, VONDRACEK P, ROPER H, LONGMAN C, KORINTHENBERG R. et al. ISPD gene mutations are a common cause of congenital and limb-girdle muscular dystrophies. Brain 2013; 136(1): 269-281. 
77. GUGLIERI M, BUSHBY K. How to go about diagnosing and managing the limb-girdle muscular dystrophies. Neurol India, 2008; 56: 271-80.

78. WICKLUND MP, KISSEL JT. The limb-girdle muscular dystrophies. Neurol Clin 2014; 32(3):729-49.

79. WALTON J, NATRASS F. On the classification, natural history and treatment of the myopathies. Brain. 1954; 77:169-231.

80. BARESI R. From proteins to genes: immunoanalysis in the diagnosis of muscular dystrophies. Skeletal Muscle. $2011 ; 1: 24$.

81. MAHMOOD O, JIANG XM. Limb-girdle muscular dystrophies: Where next after six decades from the first proposal. Mol Med Rep, 2014; 9(5): 1515-1532.

82. NIGRO V, SAVARESE M. Genetic basis of limb-girdle muscular dystrophies: the 2014 update. Acta Myologica 2014; $32: 1-12$.

83. COTTA A, CARVALHO E, LOPES DA-CUNHA A, et al. Common recessive limb girdle muscular dystrophies differential diagnosis: why and how? Arq Neuropsiquiatr, 2014; 72(9):721-734.

84. NORWOOD FL, HARLING C, CHINNERY PF, EAGLE M, BUSHBY K, STRAUB V. Prevalence of genetic muscle disease in Northern England: in-depth analysis of a muscle clinic population. Brain. 2009; 132:3175-3186.

85. GOMEZ-DIAZ B, ROSAS-VARGAS H, ROQUE-RAMIREZ B, et al. Immunodetection analysis of muscular dystrophies in Mexico. Muscle Nerve. 2012; 45:338-345.

86. DINIZ G, ERYAŞAR G, TÜRE S, et al. A regional panorama of dysferlinopathies. Turk Patoloji Derg. 2012; 28: 259-265.

87. FANIN M, NASCIMBENI AC, FULIZIO L, et al. The frequency of limb girdle muscular dystrophy $2 \mathrm{~A}$ in northeastern Italy. Neuromuscul Disord 2005; 15:218-24.

88. STEHLÍKOVÁ K, SKÁLOVÁ D, ZÍDKOVÁ J, MRÁZOVÁ L, MAZANEC R, VOHANKA S, HABERLOVA J, HERMANOVA M, ZAMECNIK J, SOUCEK O, OŠLEJŠKOVÁ H, DVOŘÁČKOVÁ N, SOLAROVA P, FAJKUSOVÁ L. Autosomal recessive limb-girdle muscular dystrophies in the Czech Republic. BMC Neurology 2014, 14:154.

89. ZATZ M, DE PAULA F, STARLING A, VAINZOF M. The 10 autosomal recessive limb-girdle muscular dystrophies. Neuromuscular disorders, 2003; 13: 532-544.

90. PENISSON-BESNIER I, HACKMAN P, SUOMINEN T, et al. Myopathies caused by homozygous titin mutations: limb-girdle muscular dystrophy $2 J$ and variations of phenotype. J Neurol Neurosurg Psychiatry 2010; 81:1200-2.

91. HALLIDAY W, GREENBERG CR, WROGEMANN K, et al. Genetic heterogeneity of limb girdle muscular dystrophy in Manitoba Hutterites. Am J Hum Genet 1998; 63 (Suppl): A 392.

92. SHOKEIR MH, KOBRINSKY NL. Autosomal recessive muscular dystrophy in Manitoba Hutterites. Clin Genet. 1976; 9(2): 197-202.

93. WEILER T, GREENBERG CR, ZELINSKI T, et al. Limb Girdle Muscular Dystrophy in Manitoba Hutterites maps to chromosome region 9q31-q33: evidence for another LGMD locus. Am J Hum Genet. 1998; 63: 140-7.

94. REILICH P, KRAUSE S, SCHRAMM N, et al. A novel mutation in the myotilin gene (MYOT) causes a severe form of limb girdle muscular dystrophy 1A (LGMD1A). J Neurol 2011; 258:1437-44.

95. HAUSER MA, HORRIGAN SK, SALMIKANGAS P, et al. Myotilin is mutated in limb girdle muscular dystrophy 1A. Hum Mol Genet, 2000; 9:2141-7.

96. SALMIKANGAS P, VAN DER VEN PF, LALOWSKI M, TAIVAINEN A, ZHAO F, SUILA H, SCHRÖDER R, LAPPALAINEN P, FÜRST DO, CARPÉN O. Myotilin, the limb-girdle muscular dystrophy $1 A$ (LGMD1A) protein, cross-links actin filaments and controls sarcomere assembly. Hum Mol Genet. 2003; 12(2): 189-203.

97. MUCHIR A, BONNE G, VAN DER KOOI AJ, et al. Identification of mutations in the gene encoding lamins A/C in autosomal dominant limbgirdle muscular dystrophy with atrioventricular conduction disturbances (LGMD1B). Hum Mol Genet 2000; 9:1453-9.

98. LAVAL SH, BUSHBY KM. Limb-girdle muscular dystrophies-from genetics to molecular pathology. Neuropathol Appl Neurobiol.2004; 30(2): 91-105.

99. POLITANO L, CARBONI N, MADEJ-PILARCZYK A, et al. Advances in basic and clinical research in laminopathies. Acta Myol, 2013; 32:18-22.

100. COUCHOUX H, BICHRAOUI H, CHOUABE C, ALTAFAJ X, BONVALLET R, ALLARD B, RONJAT M, BERTHIER C. Caveolin-3 is a direct molecular partner of the Cav 1.1 subunit of the skeletal muscle L-type calcium channel. The International Journal of Biochemistry \& Cell Biology, 2011; 43 (5): 713-720.

101. GAZZERRO E, SOTGIA F, BRUNO C, LISANTI MP, MINETTI C. Caveolinopathies: from the biology of caveolin-3 to human diseases. European Journal of Human Genetics. 2010; 18: 137-145.

102. LO HP, BERTINI E, MIRABELLA M, DOMAZETOVSKA A, DALE RC, PETRINI S, D’AMICO A, VALENTE EM, BARRESI R, ROBERTS M, TOZZI G, TASCA G, COOPER ST, et al. Mosaic caveolin-3 expression in acquired rippling muscle disease without evidence of myasthenia gravis or acetylcholine receptor autoantibodies. Neuromuscular Disorders, 2011; 21 (3): 194-203.

103. MINETTI C, SOTGIA F, BRUNO C, SCARTEZZINI P, BRODA P, BADO M, MASETTI E, MAZZOCCO M, EGEO A, DONATI M A, VOLONTÉ D, GALBIATI F, CORDONE G, et al. Mutations in the caveolin-3 gene cause autosomal dominant limb-girdle muscular dystrophy. Nature Genetics, 1998; 18: 365-368.

104. CARBONE I, BRUNO C, SOTGIA F, BADO M, BRODA P, MASETTI E, PANELLA A, ZARA F, BRICARELLI FD, CORDONE G, LISANTI MP, MINETTI C. Mutation in the CAV3 gene causes partial caveolin-3 deficiency and hyperCKemia. Neurology. 2000; 54(6):1373-6.

105. MERLINI L, CARBONE I, CAPANNI C, SABATELLI P, TORTORELLI S, LISANTI MP, BRUNO C, MINETTI C. Familial isolated hyperCKaemia associated with a new mutation in the caveolin-3 (CAV-3) gene. J Neurol Neurosurg Psychiatry. 2002; 73(1):65-7.

106. WOODMAN SE, SOTGIA F, GALBIATI F, MINETTI C, LISANTI MP. Caveolinopathies: mutations in caveolin-3 cause four distinct autosomal dominant muscle diseases. Neurology.2004; 62(4):538-43. 
107. PETERLE E, FANIN M, SEMPLICINI C, et al. Clinical phenotype, muscle MRI and muscle pathology of LGMD1F. J Neurol, 2013; 260:2033-41.

108. VIEIRA NM, NASLAVSKY MS, LICINIO L, et al. A defect in the RNA processing protein HNRPDL causes limb-girdle muscular dystrophylG (LGMD1G). Hum Mol Genet 2014 [Epub ahead of print].

109. STARLING A, KOK F, PASSOS-BUENO MR, et al. A new form of autosomal dominant limb-girdle muscular dystrophy (LGMD1G) with progressive fingers and toes flexion limitation maps to chromosome 4p21. Eur J Hum Genet 2004; 12: 1033-40.

110. BISCEGLIA L, ZOCCOLELLA S, TORRACO A, et al. A new locus on 3p23-p25 for an autosomal-dominant limb-girdle muscular dystrophy, LGMD1H. Eur J Hum Genet 2010; 18: 636-41.

111. FARDEAU M, HILLAIRE D, MIGNARD C, FEINGOLD N, FEINGOLD J, MIGNARD D, DE UBEDA B, COLLIN H, TOME FM, RICHARD I, BECKMANN J. Juvenile limb-girdle muscular dystrophy: clinical, histopathological and genetic data from a small community living in the Reunion Island. Brain 1996; 119: 295-308.

112. PATHAK P, SHARMA MC, SARKAR C, et al. Limb girdle muscular dystrophy type $2 A$ in India: a study based on semiquantitative protein analysis, with clinical and histopathological correlation. Neurol India, 2010; 58:549-54.

113. WEILER T, BASHIR R, ANDERSON LV, et al. Identical mutation in patients with limb girdle muscular dystrophy type $2 B$ or Miyoshi myopathy suggests a role for modifier gene (s). Hum Mol Genet, 1999; 8:871-7.

114. CACCIOTTOLO M, NUMITONE G, AURINO S, et al. Muscular dystrophy with marked Dysferlin deficiency is consistently caused by primary dysferlin gene mutations. Eur J Hum Genet. 2011; 19:974-80.

115. NOGUCHI S, MCNALLY EM, BEN OTHMANE K, et al. Mutations in the dystrophin-associated protein gamma-sarcoglycan in chromosome13 muscular dystrophy. Science. 1995; 270:819-22.

116. LIM LE, DUCLOS F, BROUX O, et al. Beta-sarcoglycan: characterization and role in limb-girdle muscular dystrophy linked to 4q12. Nat Genet. 1995; 11:257-65.

117. ROBERDS SL, LETURCQ F, ALLAMAND V, et al. Missense mutations in the adhalin gene linked to autosomal recessive muscular dystrophy. Cell 1994; 78:625-33.

118. MOREIRA ES, WILTSHIRE TJ, FAULKNER G, et al. Limb-girdle muscular dystrophy type $2 G$ is caused by mutations in the gene encoding the sarcomeric protein telethonin. Nat Genet 2000;24:163-6.

119. LOCKE M, TINSLEY CL, BENSON MA, et al. TRIM32 is an E3 ubiquitin ligase for dysbindin. Hum Mol Genet 2009; 18:2344-58.

120. FROSK P, WEILER T, NYLEN E, et al. Limb-girdle muscular dystrophy type $2 H$ associated with mutation in TRIM32, a putative E3-ubiquitin-ligase gene. Am J Hum Genet 2002; 70: 663-72.

121. BROWN SC, TORELLI S, BROCKINGTON M, YUVA Y, JIMENEZ C, FENG L, ANDERSON L, UGO I, KROGER S, BUSHBY K, VOIT T, SEWRY C, MUNTONI F. Abnormalities in alpha-dystroglycan expression in MDC1C and LGMD2I muscular dystrophies. American Journal of Pathology, 2004, 164 (2):727-37.

122. LIANG W-C, HAYASHI YK, OGAWA M, WANG C-H, HUANG W-T, NISHINO I, JONG Y-J. Limb-girdle muscular dystrophy type 2I is not rare in Taiwan, Neuromuscular Disorders, 2013, 23 (8): 675-681.

123. BROCKINGTON M, BLAKE DJ, PRANDINI P, et al. Mutations in the fukutin-related protein gene (FKRP) cause a form of congenital muscular dystrophy with secondary laminin alpha2 deficiency and abnormal glycosylation of alpha-dystroglycan. Am J Hum Genet, 2001; 69:1198-209.

124. MERCURI E, BROCKINGTON M, STRAUB V, et al. Phenotypic spectrum associated with mutations in the fukutin-related protein gene. AnnNeurol, 2003; 53:537-42.

125. GERULL B, GRAMLICH M, ATHERTON J, et al. Mutations of TTN, encoding the giant muscle filament titin, cause familial dilated cardiomyopathy, Nat Genet 2002; 30:201-4.

126. CHONG YK, KWAN MA LC, LO KL, LAI LEE CK, MAK CM, CHI KAN AN, LAM CW. Dystroglycanopathy with two novel POMT1 mutations in a Chinese boy with developmental delay and muscular dystrophy. European Journal of Paediatric Neurology, 2014 [Epub ahead of print].

127. BEHIN A, LETURCQ F, COSSÉE M, WAHBI K, DEBURGRAVE N, BÉCANE H-M, CARLIER R-Y, LAFORÊT P, STOJKOVIC T, CARLIER P, EYMARD B. Anoctamin 5 myopathy: More patients, more phenotypes. Journal of the Neurological Sciences, 2013, 333 (Suppl. 1): e47.

128. BOLDUC V, MARLOW G, BOYCOTT KM, SALEKI K, INOUE H., KROON J, ITAKURA M, ROBITAILLE Y, PARENT L, BAAS F, et al. Recessive Mutations in the Putative Calcium-Activated Chloride Channel Anoctamin 5 Cause Proximal LGMD2L and Distal MMD3 Muscular Dystrophies. The American Journal of Human Genetics. 2010; 86:213-221.

129. BOUQUET F, COSSEE M, BEHIN A, DEBURGRAVE N, ROMERO N, LETURCQ F, EYMARD B. Miyoshi-like distal myopathy with mutations in anoctamin 5 gene (Myopathie de type Miyoshi associée à des mutations du gène de l'anoctamine 5). Revue Neurologique. 2012; 168 (2): 135-141.

130. HICKS D, SARKOZY A, MUELAS N, KÖEHLER K, HUEBNER A, HUDSON G, CHINNERY PF, BARRESI R, EAGLE M, et al. A founder mutation in Anoctamin 5 is a major cause of limb girdle muscular dystrophy. Brain. 2011; 134 (1): 171-182.

131. LITTLE A, MCKEEVER P, GRUIS K. Novel mutations in the anoctamin 5 gene (ANO5) associated with limb-girdle muscular dystrophy 2L. Muscle \& Nerve, 2013; 47 (2): 287-291.

132. MAGRI F, DEL BO R, D'ANGELO MG, SCIACCO M, GANDOSSINI S, GOVONI A, NAPOLI L, CISCATO P, et al. Frequency and characterisation of anoctamin 5 mutations in a cohort of Italian limb-girdle muscular dystrophy patients. Neuromuscular Disorders, 2012; 22 (11): 934-943.

133. MAHJNEH I, JAISWAL J, LAMMINEN A, SOMER M, MARLOW G, KIURU-ENARI S, BASHIR R. A new distal myopathy with mutation in anoctamin 5. Neuromuscular Disorders, 2010; 20 (12): 791-795.

134. RAJ JOSHI P, GLÄSER D, DREßEL C, KRESS W, WEIS J, DESCHAUER M. Anoctamin 5 muscular dystrophy associated with a silent p.Leu115Leu mutation resulting in exon skipping. Neuromuscular Disorders, 2014; 24 (1): 43-47. 
135. SARKOZY A, HICKS D, HUDSON J, LAVAL SH, BARRESI R, HILTON-JONES D, DESCHAUER M, HARRIS E, et al. ANO5 Gene Analysis in a Large Cohort of Patients with Anoctaminopathy: Confirmation of Male Prevalence and High Occurrence of the Common Exon 5 Gene Mutation. Human Mutation. 2013; 34 (8): 1111-1118.

136. SCHESSL J, KRESS W, SCHOSER B. Novel ANO5 mutations causing hyper-CK-emia, limb girdle muscular weakness and Miyoshi type of muscular dystrophy. 2012; Muscle \& Nerve, 45 (5): 740-742.

137. WAHL CM, VAN GHELUE M, ARNTZEN KA, HALVORSEN H, INGEBRIGTSEN M, SKOGSTAD A, HESTHOLM B, LØSETH S, MELLGREN SI, RASMUSSEN F, LINDAHL S, JONSRUD C. Mutations in anoctamin 5 in limb girdle muscular dystrophy in Norway: Phenotypic variability and mutation spectrum. Journal of the Neurological Sciences, 2013; 333 (SUPPL. 1): E444.

138. WITTING N, DUNO M, PETRI H, KRAG T, BUNDGAARD H, KOBER L, VISSING J. Anoctamin 5 muscular dystrophy in Denmark: prevalence, genotypes, phenotypes, cardiac findings, and muscle protein expression. Journal of Neurology, $2013 ; 260$ (8): 2084-2093.

139. TIAN Y, SCHREIBER R, KUNZELMANN K. Anoctamins are a family of Ca2+-activated Cl- channels. J Cell Sci; 125:4991-8.

140. MERCURI E, MESSINA S, BRUNO C, et al. Congenital muscular dystrophies with defective glycosylation of dystroglycan: a population study. Neurology, 2009;72: 1802-9.

141. PUCKETT RL, MOORE SA, WINDER TL, et al. Further evidence of Fukutin mutations as a cause of childhood onset limbgirdle muscular dystrophy without mental retardation. Neuromuscul Disord, 2009;19:352-6.

142. BIANCHERI R, FALACE A, TESSA A, et al. POMT2 gene mutation in limb-girdle muscular dystrophy with inflammatory changes. Biochem Biophys Res Commun, 2007; 363:1033-7.

143. PANE M, MESSINA S, VASCO G, FOLEY AR, MORANDI L, PEGORARO E, MONGINI T, D'AMICO A, BIANCO F, LOMBARDO ME, SCALISE R., BRUNO C, BERARDINELLI A, et al. Respiratory and cardiac function in congenital muscular dystrophies with alpha dystroglycan deficiency. Neuromuscular Disorders, 2012; 22 (8): 685-689.

144. CLEMENT EM, GODFREY C, TAN J, et al. Mild POMGNT1 mutations underlie a novel limb-girdle muscular dystrophy variant. Arch Neurol, 2008; 65:137-41.

145. RADUCU M, BAETS J, FANO O, et al. Promoter alteration causes transcriptional repression of the POMGNT1 gene in limbgirdle muscular dystrophy type 20. Eur J Hum Genet, 2012.

146. GODFREY C, FOLEY AR, CLEMENT E, MUNTONI F. Dystroglycanopathies: coming into focus. Current Opinion in Genetics \& Development. 2011; 21 (3): 278-285.

147. HARA Y, BALCI-HAYTA B, YOSHIDA-MORIGUCHI T, KANAGAWA M, BELTRÁN-VALERO DE BERNABÉ D, GÜNDEŞLI H, WILLER T, SATZ JS, CRAWFORD RW, et al. A Dystroglycan Mutation Associated with Limb-Girdle Muscular Dystrophy. New Engl. J. Med. 2011; 364(10): 939-946.

148. GUNDESLI H, TALIM B, KORKUSUZ P, et al. Mutation in exon If of PLEC, leading to disruption of plectin isoform $1 f$, causes autosomal-recessive limb-girdle muscular dystrophy. Am J Hum Genet 2010; 87:834-41.

149. CETIN N, BALCI-HAYTA B, GUNDESLI H, et al. A novel desmin mutation leading to autosomal recessive limb-girdle muscular dystrophy: distinct histopathological outcomes compared with desminopathies. J Med Genet 2013; 50:437-43.

150. BOGERSHAUSEN N, SHAHRZAD N, CHONG JX, et al. Recessive TRAPPC11 mutations cause a disease spectrum of limb girdle muscular dystrophy and myopathy with movement disorder and intellectual disability. Am J Hum Genet; 93:181-90. 87:834-41.

151. SCRIVENS PJ, SHAHRZAD N, MOORES A, et al. TRAPPC2L is a novel, highly conserved TRAPP-interacting protein. Traffic 2009; 10:724-36.

152. CARSS KJ, STEVENS E, FOLEY AR, CIRA K, RIEMERSMA M, TORELLI S, HOISCHEN A, WILLER T, VAN SCHERPENZEEL M, MOORE SA, et al. Mutations in GDP-Mannose Pyrophosphorylase B Cause Congenital and LimbGirdle Muscular Dystrophies Associated with Hypoglycosylation of $\alpha$-Dystroglycan. The American Journal of Human Genetics. 2013; 93 (1): 29-41.

153. CIRAK S, FOLEY AR, HERRMANN R, WILLER T, YAU S, STEVENS E, TORELLI S, BRODD L, KAMYNINA A, VONDRACEK P, ROPER H, LONGMAN C, KORINTHENBERG R, et al. ISPD gene mutations are a common cause of congenital and limb-girdle muscular dystrophies. Brain 2013; 136(1): 269-281.

154. GUGLIERI M, BUSHBY K. How to go about diagnosing and managing the limb-girdle muscular dystrophies. Neurol India, 2008; 56:271-80.

Received February 10, 2015 